\title{
STUDI PENDETEKSIAN DINI BAWAH PERMUKAAN SITUS PURBAKALA BERBASIS KOMBINASI METODE GEOLISTRIK DENGAN METODE GEOMAGNETIK DI TAPANULI TENGAH
}

\author{
Asdiati Berutu ${ }^{1)}$, Jamaludin Hasibuan ${ }^{2)}$, Halimahtun Sakdiah ${ }^{3)}$, Rahmatsyah ${ }^{4)}$ \\ ${ }^{1,2,3,4)}$ FMIPA, Universitas Negeri Medan \\ e-mail: jamalhasibuan46@gmail.com \\ asdiati.berutu01@gmail.com \\ syakdiahhalimahtun16@gmail.com \\ rahmatunimed@gmail.com
}

\begin{abstract}
Abstrak
Bangsa Indonesia terkenal sebagai bangsa yang memiliki warisan budaya bernilai tinggi, salah satunya adalah peninggalan situs purbakala Kerajaan Barus di Lobu Tua Kabupaten Tapanuli Tengah, telah dilakukan penelitian studi pendeteksian dini bawah permukaan situs purbakala berbasis kombinasi metode geolistrik dengan metode geomagnetik di Tapanuli Tengah,yang bertujuan untuk mengetahui bawah permukaan situs purbakala dengan menggunakan kombinasi metode geolistrik dan metode geomagnetik. Hasil penelitian geolistrik diperoleh daerah penelitian didominasi dengan batuan aluvium dengan nilai resistivitas 55,3 - 705 terdapat pada kedalaman 6 m - 30 m dan Tufa dengan nilai resistivitas 2600 - 4601 terdapat pada kedalaman $1,25 \mathrm{~m}-6 \mathrm{~m}$ dan jenis batuan andesit dengan nilai resistivitas $500-2300$. Hasil penelitian menggunakan metode geomagnetik Secara kualitatif terdapat anomali magnetik bernilai tinggi yaitu -90 nT, dengan nilai suseptibilitas berkisar antara 0,714 - 0,994 ditafsirkan sebagai batu pasir dan nilai suseptibilitas 1,008 - 1,261 ditafsirkan sebagai batuan alluvium, sehingga daerah penelitian situs purbakala kerajaan barus didominasi dengan batuan aluvium. Dimana dari kedua metode tersebut dapat di interpretasikan bahwa batuan penyusun situs purbakala kerajaan Barus yaitu batuan alluvium.
\end{abstract}

Kata Kunci: Metode geolistrik, metode geomagnet, situs purbakala

\begin{abstract}
Indonesian nation is renown as a nation that has cultural heritage of high value, one of them is the relics of archaeological sites of Barus Kingdom in Lobu Tua Tapanuli Tengah regency. Have to be investigated using study early detection of the presence of archaeological sites by based combintion geoelectric method with geomagnetic which aims to determine the presence of the sites in Lobu Tua based combination geoelectric method with geomagnetic. Date processing is done by geoelectric research area is dominated by alluvium rock with the resistivity 55,3-705 at depth $6 \mathrm{~m}-30 \mathrm{~m}$ and tuff with the resistivity $2600-4601$ at depth 1,25 $m-6 m$ and andesite rocks with the resistivity 500 - 2300. Qualitatively, the result shows there are magnetic anomalies part with high value is $-90 \mathrm{nT}$, susceptibility value ranged between 0,714-0,994 interpreted with sand and susceptibility value ranged between 1,008 - 1,261 interpreted with alluvium rocks. So the research area of archaeological sites in the city of Barus dominated by alluvium rock. Where from of both methods can be interpreted rock archaeological sites in the city of Barus with alluvium rocks.
\end{abstract}

Keywords : Geoelectric method, geomagnetic method, archaeological sites 


\section{Pendahuluan}

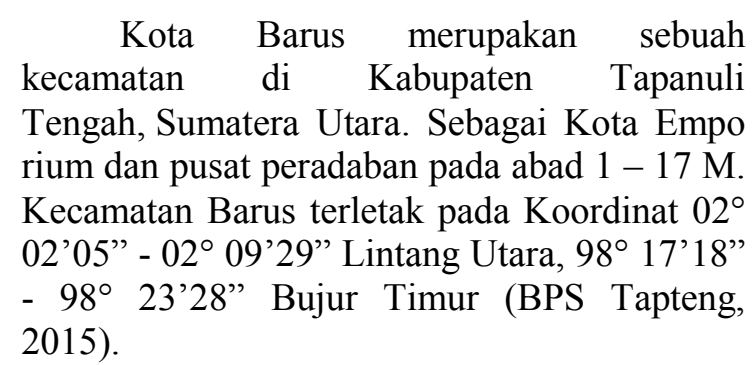

Kota Barus merupakan Kota bersejarah yang memiliki berbagai peninggalan purba kala, salah satunya yang terdapat di Desa Lobu Tua. Dihuni dalam jangka waktu sekitar dua abad antara akhir abad ke-9 $\mathrm{M}$ hingga awal abad ke-12 M (Claude Guillot,2002).

Lokasi situs Lobu Tua pernah dilakukan penelitian arkeologi dengan eskavasi (penggalian) beberapa kali. Diantaranya penelitian tahun 1978 dan 1985 yang dipimpin oleh M.M. Nurhadi dan Lukman Nurhakim dari Pusat Penelitian Akeologi Nasional. Meng hasilkan antara lain lebih dari 300 pecahan keramik Cina (sebagian besar dari Dinasti Song), pecahan-pecahan tembikar, kaca, logam, dan manik-manik (Claude Guillot, 2008).

Berdasarkan hasil wawancara terhadap masyarakat Lobu Tua bahwa didaerah yang akan diteliti, dahulu adanya informasi tentang situs purbakala yang belum ditemukan keberadaannya secara sains dan diperkuat berdasarkan buku karangan Claude Guillot yang berjudul Lobu Tua Sejarah Awal Barus. Teramati melalui foto udara di Desa Lobu Tua di apit oleh dua sungai diperkirakan daerah Lobu Tua terdapat banyak peninggalan kerajaan terdahulu baik berupa bangunan, makam, atau artefak-artefak.

Mendeteksi ada tidaknya peninggalan situs purbakala yang masih terkubur maka diperlukan metode dan alat ukur yang dapat mengukur parameter-parameter fisis yang berhubungan dengan keberadaan benda-benda peninggalan situs purbakala tersebut. Metode yang digunakan untuk mendeteksi peninggalan situs purbakala tersebut dengan menggunakan Metode geolistrik dan geomagnet (Kanata \& Zubaidah, 2008).

Kajian Literatur yang menjadi landasan penelitian ini yaitu: situs Lobu Tua, metode geolistrik, dan metode geomagnet sebagai mana dijelaskan berikut ini.

\section{Situs Lobu Tua}

Situs Lobu Tua merupakan salah satu situs kuno daerah Barus, Pada tahun 1873 kontrolir Belanda yang bertugas di Barus menemukan benda-benda kuno di Lobu Tua berupa empat prasasti, dan tahun 1844 pada waktu kegiatan pertanian dilakukan untuk memperkenalkan tanaman lada, kekunoan situs Lobu Tua terbukti dengan penemuan bendabenda kuno, seperti perhiasan serta mata uang dari emas dan perak (Claude Guillot, 2002).

\section{Metode Geolistrik}

Metode geolistrik adalah salah satu metode yang digunakan untuk mengetahui kondisi di bawah permukaan tanah. Metode dari geolistrik yang sering digunakan antara lain tahanan jenis atau resistivitas. Metode Geolistrik menggunakan nilai tahanan jenis di bawah permukaan untuk menentukan dan mempelajari jenis lapisan penyusun dan banyaknya lapisan penyusun bawah permu kaan tanah (Danang, 2013).

Survei dengan menggunakan metode Geolistrik telah dilakukan oleh Danang Rubawa Tamtama (2013) didaerah situs purba kala Kadisoka. Bertujuan untuk mengetahui sebaran batuan candi Kadisoka yang masih terpendam di dalam tanah, hasil dari penelitian menunjukan adanya anomali batuan penyusun situs Kadisoka yang masih terpendam di beberapa titik. Ditunjukan dengan nilai resitivitas antara $500 \Omega \mathrm{m}$ sampai dengan 2300 $\Omega \mathrm{m}$ yang berarti nilai resitivitas dari andesit.

Metode Geofisika untuk mendeteksi situs purbakala pernah dilakukan oleh E Galili, et al. (1988) di Creole ruralsettlements bagian tenggara Provinsi Buenos Aires, Argentina. Yang bertujuan untuk mendeteksi penyebaran benda-benda purbakala dan menentukan struktur perlapisan tanah dengan metode Geofisika. Hasil dari yaitu ditemukannya benda-benda seperti tulang-tulang, kaca dan batuan penyusun situs purbakala tersebut (Galili, et al., 1988).

Identifikasi situs candi telah dilakukan oleh Diah Sri Jayanti, Darsono, dan Budi Legowo di situs candi di wilayah Bukit Carang, Desa Anggrasmanis, Kecamatan Jenawi, Kabupaten Karanganyar, Jawa Tengah dengan menggunakan metode geolistrik tahanan jenis konfigurasi dipol-dipol. Metode ini dapat menentukan keberadaan situs yang 
masih terpendam di sekitar lokasi penemuan pondasi candi (Diah Sri Jayanti, et al, 2012).

\section{Metode Geomagnet}

Metode geomagnet adalah salah satu metode geofisika yang memanfaatkan sifat kemagnetan bumi. Dalam survei dengan metode geomagnet yang menjadi target dari pengukuran adalah variasi medan magnetik yang terukur di permukaan (anomali mag netik) (Soemantri, 2003).

Medan magnet utama bumi berubah terhadap waktu. Untuk menyeragamkan nilainilai medan utama magnet bumi, dibuat standar nilai yang disebut International Geomagnetics Reference Field (IGRF) yang diperbaharui setiap 5 tahun sekali. Nilai-nilai IGRF tersebut diperoleh dari hasil pengukuran rata-rata pada daerah luasan sekitar 1 juta $\mathrm{km}^{2}$ yang dilakukan dalam waktu satu tahun (Telford, 1976).

Survei dengan menggunakan geomagnetik juga pernah dilakukan oleh S. Y. Moussavi Alashloo, dkk (2011) di daerah situs purbakala Sungai Batu, Kedah, Malaysia. Penelitian tersebut bertujuan untuk mencari benda-benda purbakala yang masih tertanam di bawah permukaan, dengan metode geomagnetik G-856 Hasil dari survei magnetik yaitu ditemukan enam anomali yang signifikan, dan dua anomali lainnya memiliki nilai magnet yang tinggi, yang berhubungan dengan reruntu han bangunan tua yang terbuat dari batu bata lumpur (Moussavi Alashloo et al., 2011).

\section{Bahan dan Metode}

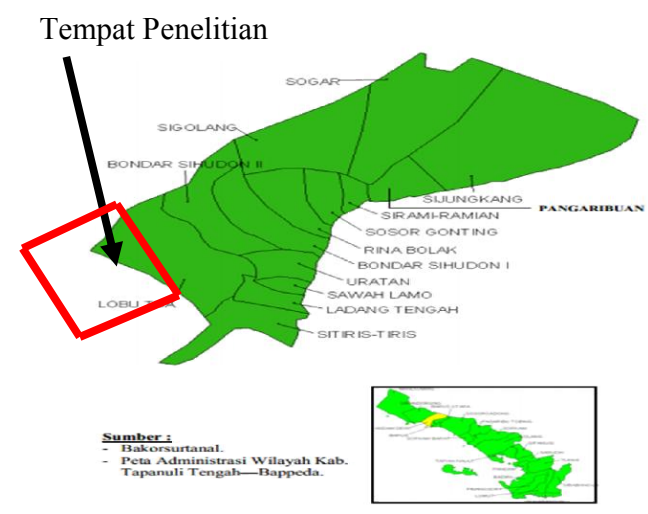

Gambar 1. Lokasi penelitian
Tempat penelitian dilakukan di Desa Lobu Tua Kecamatan Andam Dewi Kabupaten Tapanuli Tengah, Propinsi Sumatra Utara dapat dilihat pada Gambar 1.

\section{Metode Geolistrik}

Data hasil menggunakan aplikasi metode geolistrik tahanan jenis dengan konfigurasi Wenner-Schlumberger di kawasan Lobu Tua, terdiri dari 4 lintasan pengukuran untuk geolistrik. Pengambilan data resitivitas dilakukan di lapangan dengan panjang lintasan 155 meter dengan spasi elektroda 5 meter. Data geolistrik diolah dan dianalisis dengan menggunakan Res2Dinv.

Prosedur Penelitian Geolistrik

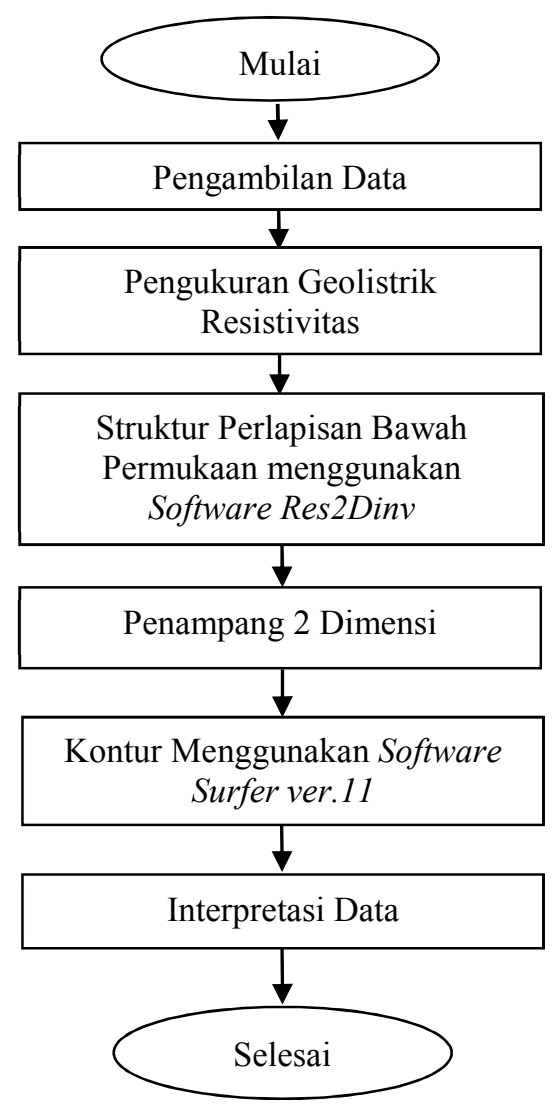

Gambar 2. Diagram alir penelitian geolistrik

Langkah-langkah yang dilakukan untuk pengambilan data geolistrik berdasarkan Gam bar 2 adalah sebagai berikut:

1. Meninjau/survei lokasi serta pengambilan gambar yang akan dijadikan sebagai daerah penelitian. 
2. Menentukan lintasan pengambilan data dan menentukan posisi daerah penelitian dengan menggunakan GPS.

3. Melakukan kalibrasi alat yang digunakan.

4. Melakukan pengukuran jarak antara elektroda (5 meter) pada lintasan yang ditentukan.

5. Pengambilan data menggunakan geolistrik ARES (Automatic Resistivity System)

6. Mengolah data yang diperoleh dari data geolistrik ARES dengan menggunakan Software Res2Dinv.

\section{Metode Geomagnetik}

Penelitian dengan menggunakan geo magnet PPM Type elsec 770 kompas geologi, GPS, Surfer 11, dan Mag2dc. Diagram alir penelitian geomagnetik menurut Gambar 3.

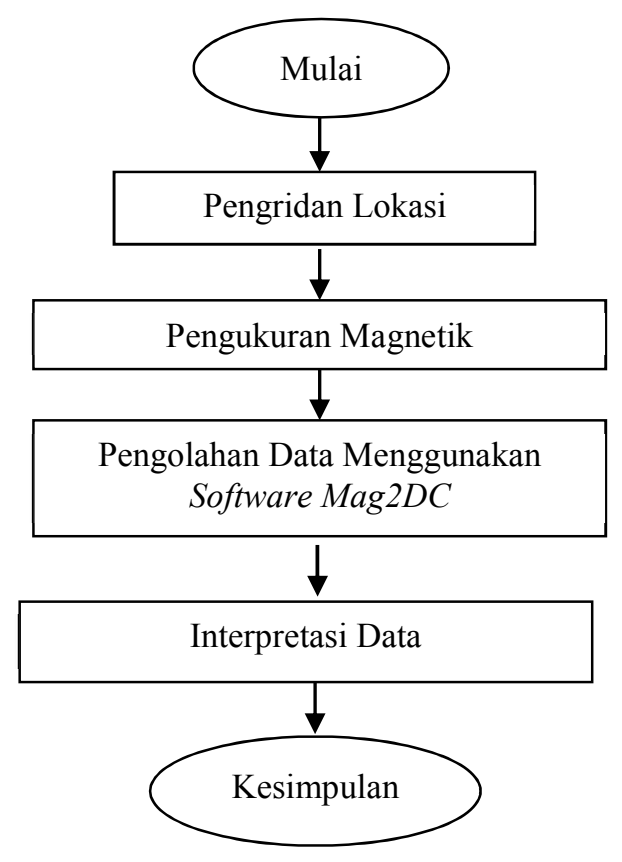

Gambar 3. Diagram alir geomagnetik

Pengolahan data dilakukan dengan menghitung koreksi variasi harian (diurnal correction), magnetik total dan nilai anomali total, ada dua jenis interpretasi dalam analisi data geomagnet, yaitu:
1. Interpretasi Kualitatif

Pengukuran secara kualitatif, analisis dilakukan pada peta kontur anomali medan magnet total dan vertikal.

2. Interpretasi Kuantitatif

Penentuan bentuk atau model dan kedala man benda anomali atau strukutur geologi melalui pemodelan matematis (HMGI, 2012)

\section{Hasil dan Pembahasan}

Hasil pengamatan data geologi berdasar kan Gambar 4 dari lokasi penelitian menunjuk kan Desa Lobu Tua terdiri dari formasi gunung api pinapan (andesite, hipabisal, dan piro klastik), formasi Sibolga (batu pasir, batu lanau, batu lumpur, dan konglomerat), Tufa Toba (tufa riodasit, sebagian teralaskan), Alluvium (kerikil, pasir, lumpur, fanglomerat kipas, tanah diatome, koral, dan formasi alas (anggota batu gamping: pejal, batu gamping hablur).

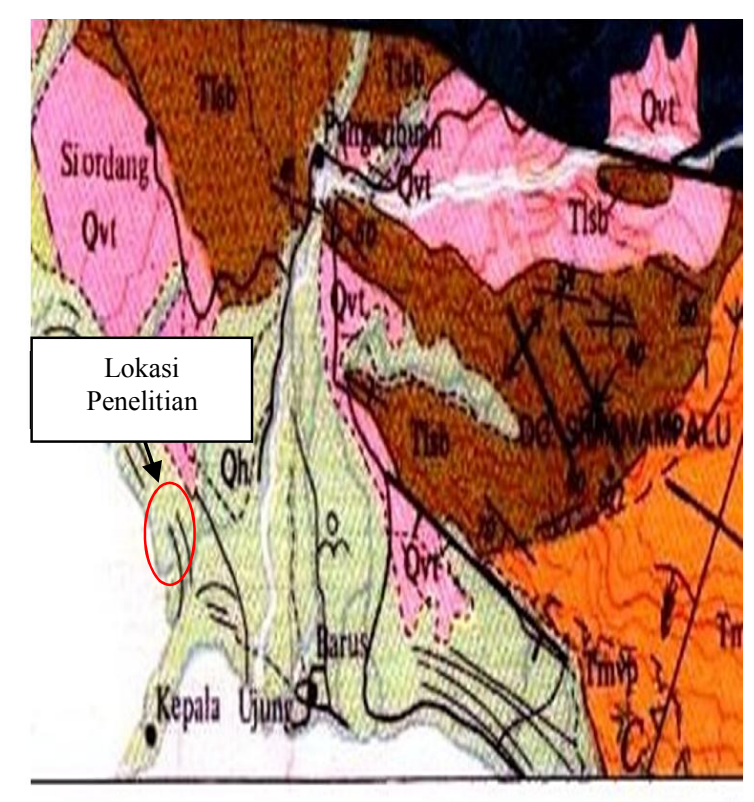

Gambar 4. Lokasi penelitian (Dinas Pertambangan dan Energi, 2017) 


\section{Hasil Penelitian Geolistrik}

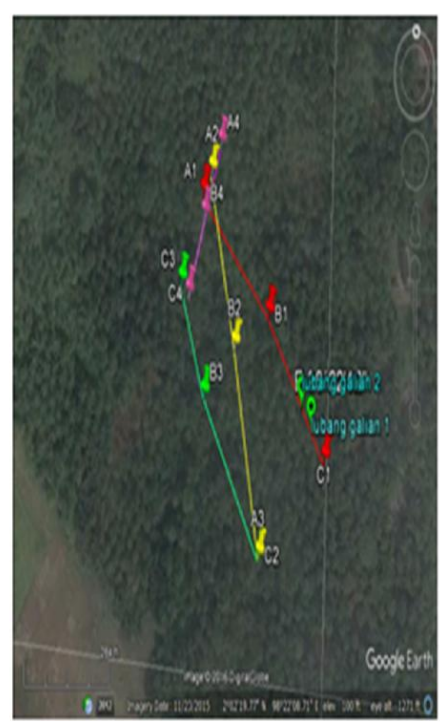

Lintasan 1

Lintasan 2

Lintasan 3

Lintasan 4

Gambar 5. Bentuk lintasan geolistrik (Google Earth, 2017)

Kontur hasil penelitian dari penggridan menggunakan GPS diolah dengan mengguna kan Software Surfer 11 dengan hasil kontur permukaan pengukuran dapat dilihat pada Gambar 6.

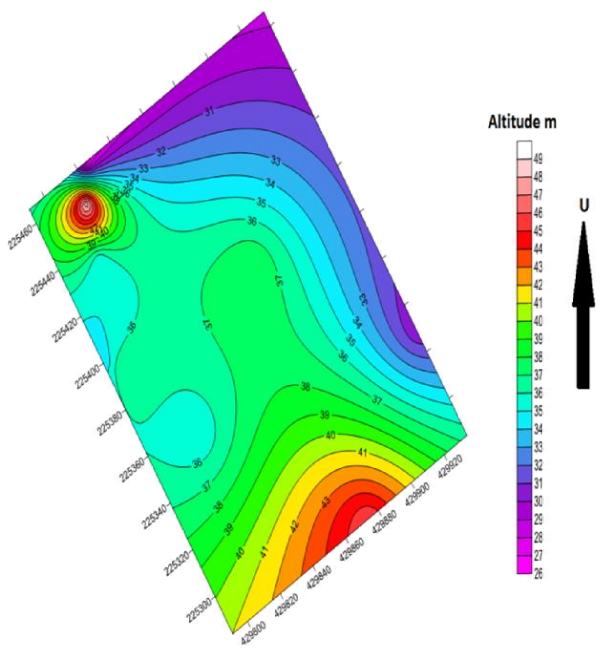

Gambar 6. Kontur lokasi penelitian

Hasil dari penggridan menunjukkan daerah penelitian berada pada ketinggian 26 meter - 49 meter dengan rata - rata ketinggian 38,5 meter. Berdasakan peta geologi lembar Barus Raya dan sekitarnya, Sumatra (Pusat Penelitian dan Pengembangan Geologi) daerah penelitian berbatasan langsung dengan laut. Hasil penelitian lintasan 1, lintasan 2 dan lintasan 3 dapat dilihat pada gambar 7, 8, dan 9 berikut :

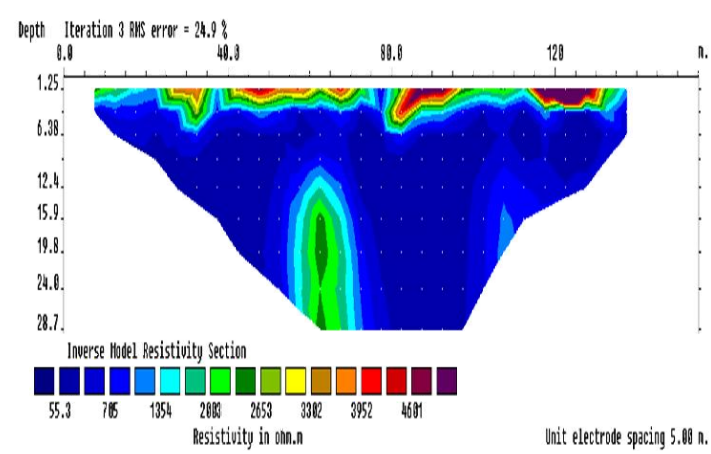

Gambar 7. Peta pseudosection lintasan 1

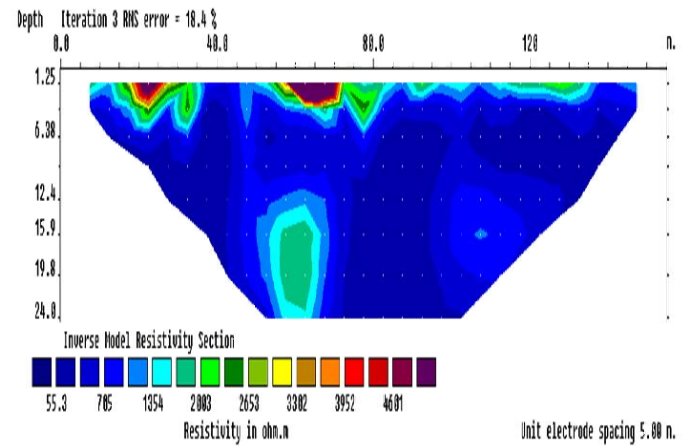

Gambar 8. Peta pseudosection lintasan 2

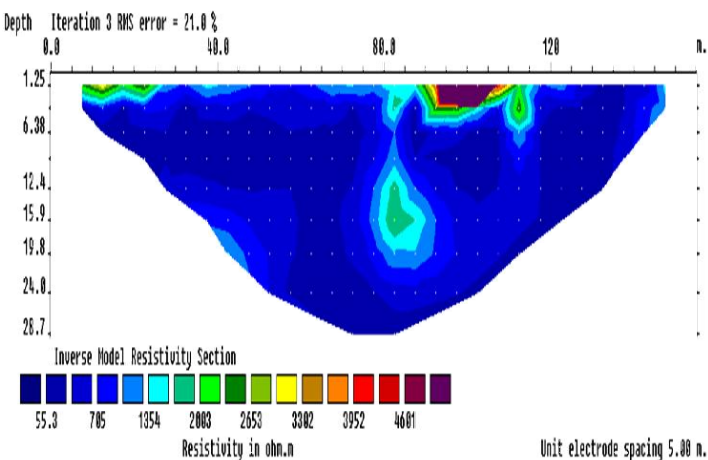

Gambar 9. Peta pseudosection lintasan 3

Lintasan 1, lintasan 2 dan lintasan 3 didominasi oleh warna biru dengan nilai resistivitas $55,3 \Omega \mathrm{m}-705 \Omega \mathrm{m}$ yang diinterpretasikan sebagai Alluvium menurut 
Telford (2004) menyatakan bahwa nilai resistivitas Alluvium $10 \Omega \mathrm{m}-800 \Omega \mathrm{m}$, dan Tufa dengan nilai resistivitas $2600 \Omega \mathrm{m}-4601$ $\Omega \mathrm{m}$ terdapat pada kedalaman $1,25 \mathrm{~m}$ sampai 6 $\mathrm{m}$ dan jenis batuan andesit dengan nilai resistivitas $500 \Omega \mathrm{m}-2300 \Omega \mathrm{m}$. Dan lintasan 4 dapat dilihat pada gambar 10 berikut :

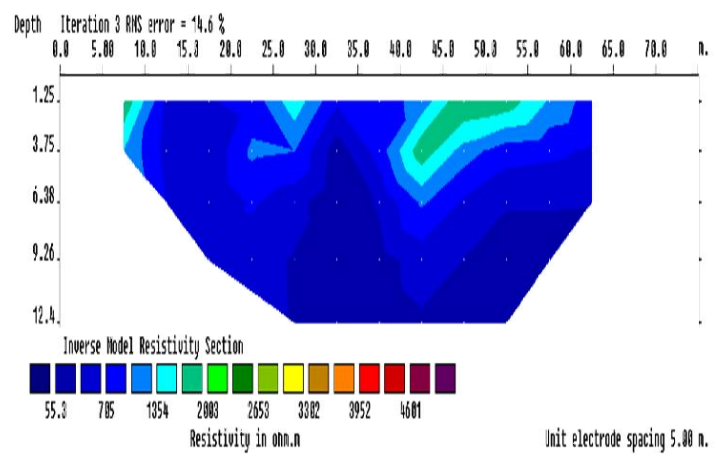

Gambar 10. Peta pseudosection lintasan 4

Pada lintasan 4 yang didominasi oleh warna biru dengan nilai resistivitas 55,3 $\Omega \mathrm{m}-$ $705 \Omega \mathrm{m}$ yang diinterpretasikan sebagai Alluvium dan dan jenis batuan andesit dengan nilai resistivitas $500 \Omega m-2300 \Omega m$.

\section{Hasil Penelitian Geomagnetik}

\section{Interpretasi Kualitatif}

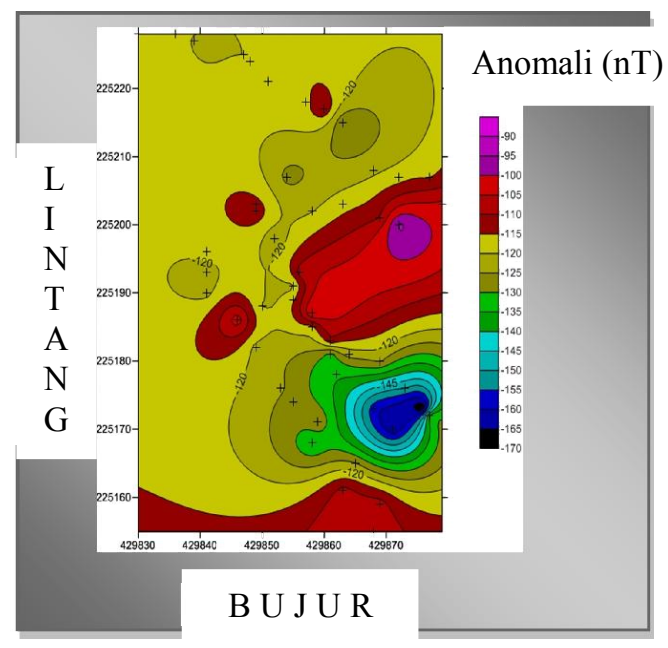

Gambar 11. Kontur anomali magnetik.

Proses pengambilan data dilakukan dengan menggunakan jarak 5 meter dan jumlah titik pengamat sebanyak 50 titik. Berikut ini merupakan bentuk kontur anomali magnetik total dari hasil perhitungan dan bentuk pemodelan Surfer 11.

Perbedaan warna pada hasil anomali tersebut merupakan nilai intensitas magnet yang berkisar antara $-170 \mathrm{nT}$ untuk nilai minimum sampai -90 nT untuk nilai maksimum, pola nilai minimum cenderung berwarna hitam dan berada pada koordinat $429872 \mathrm{~N}$ dan $225200 \mathrm{E}$ dan nilai anomali magnetik maksimum berkisar $-90 \quad$ nT cenderung berwarna ungu yang berada pada koordinat $429871 \mathrm{~N}$ dan $225173 \mathrm{E}$.

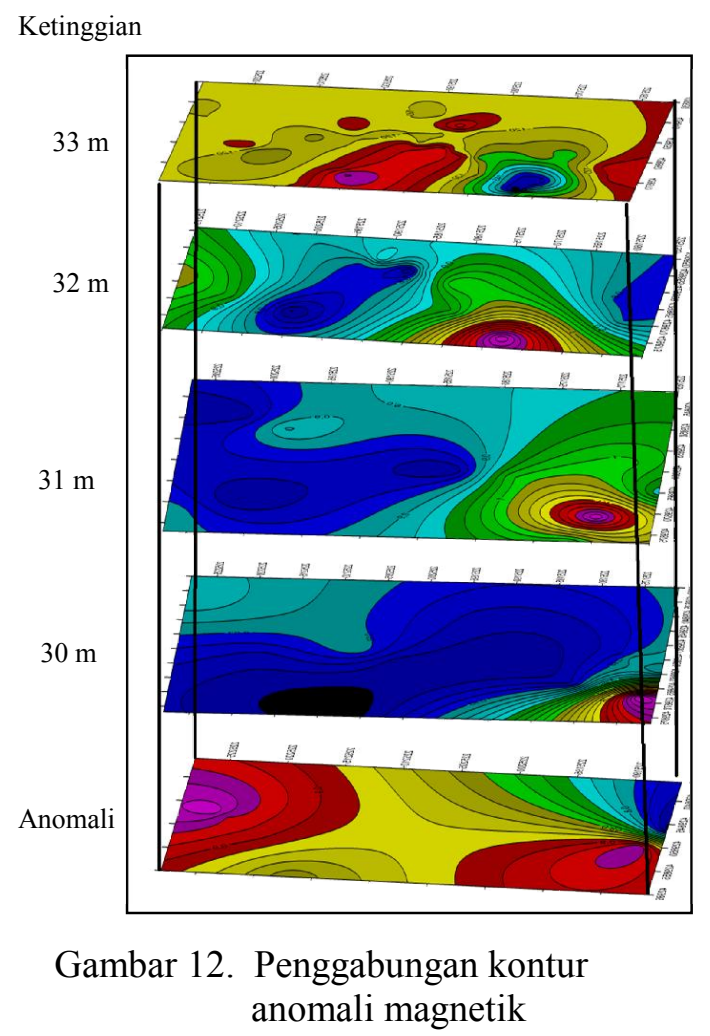

Pada Gambar 12, terlihat adanya Pendominanan bentuk anomali. Dimana semakin tinggi upward dilakukan, maka bentuk anomali semakin jelas terlihat. Pada kontinuasi upward $33 \mathrm{~m}$ bentuk anomali sudah semakin terdominankan. Semakin terlihat jelas dugaan adanya bentuk anomali magnetik. Semakin keatas, semakin terlihat jelas dominasi dari dugaan bentuk anomalinya. Diduga terdapat dua bentuk anomali yaitu yang ditandai dengan warna merah dan ungu. 


\section{Interpetasi Kuantitatif}

Untuk menggambarkan struktur bawah permukaan dari pengukuran data. Interpretasi dilakukan dengan membuat model penampang geomagnetik menggunakan software Mag2DC dengan menginput data, sehingga akan diperoleh Gambar 13 yaitu gambar yang menunjukkan nilai suseptibilitas dan warna berdasarkan lapisan batuan. Dalam melakukan pemodelan numerik diperlukan beberapa paremeter medan magnetik bumi daerah penelitian yang meliputi nilai IGRF $(42125,1$ nT), sudut deklinasi $\left(-0.3945^{\circ}\right)$, sudut inklinasi $\left(-12.9647^{\circ}\right)$, serta beberapa parameter pemodelan, sehingga diproleh Gambar 13 berikut:

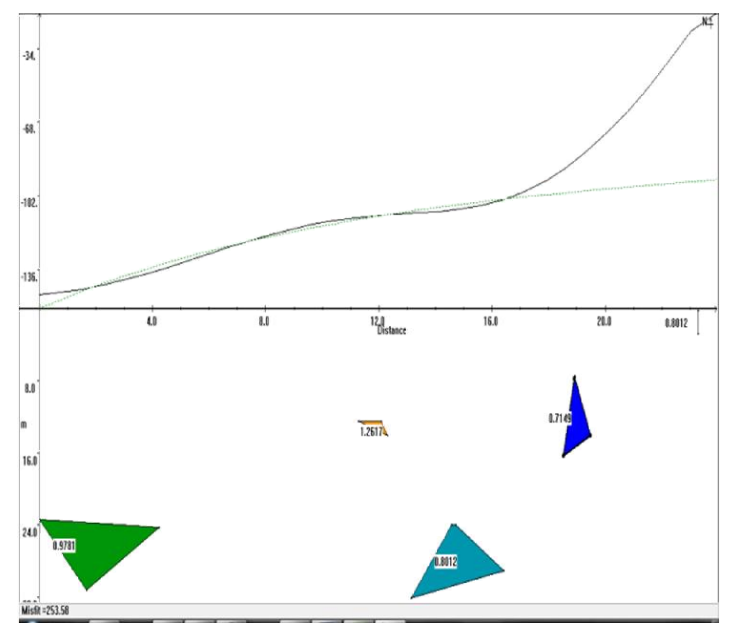

Gambar 13. Model penampang geomagnetik menggunakan software Mag2dc

Gambar 13 menunjukkan model penampang yang melintang AA' dimana pada gambar tersebut terdapat sumbu $\mathrm{x}$ dan sumbu $\mathrm{y}$. Sumbu $\mathrm{x}$ menunjukkan panjang sayatan, sumbu y positif menunjukkan nilai variasi intensitas magnetik dan sumbu y negatif menunjukkan kedalaman. Dari hasil pemodelan dapat ditentukan litologi batuan berdasarkan nilai suseptibilitas.

Nilai $k=0,714$ sampai $k=0,994$ di interpretasikan sebagai pasir lapisan ini berada pada kedalaman 0 hingga 25 meter, Kebanyakan batu pasir di bentuk dari butiranbutiran yang terbawa oleh pergerakan air, seperti ombak pada suatu pantai atau saluran di suatu sungai. Nilai suseptibilitas $k=1,008$ sampai $\mathrm{k}=1,261$ berada pada pada kedalaman 4 hingga 25 meter, ditafsirkan sebagai lapisan batuan alluvium. Batuan aluvium adalah batuan sedimen yang dibentuk atau diendapkan oleh sungai atau air laut. Dimana lokasi penelitian merupakan daerah yang diapit oleh dua sungai dan bersebelahan langsung dengan laut Samudera Hindia.

\section{Kesimpulan dan Saran}

Berdasarkan hasil penelitian diperoleh kesimpulan yaitu:

1. Hasil penelitian situs purbakala Lobu Tua menggunakan metode geolistrik resitivitas konfigurasi Wenner-Schlumberger bahwa di daerah penelitian didominasi dengan jenis batuan alluvium dengan nilai resistivitas 55,3 $\Omega \mathrm{m}-705 \Omega \mathrm{m}$ dan Tufa dengan nilai resistivitas $2600 \Omega \mathrm{m}-4601$ $\Omega \mathrm{m}$ terdapat pada kedelaman $1,25 \mathrm{~m}$ sampai $6 \mathrm{~m}$ dan jenis batuan andesit dengan nilai resistivitas $500 \Omega \mathrm{m}-2300 \Omega \mathrm{m}$.

2. Hasil penelitian, menggunakan metode geomagnetik di situs purbakala Lobu Tua diperoleh nilai anomali magnetik total barkisar antara $-170 \mathrm{nT}$ sampai dengan -90 nT. Dari pemodelan yang telah dilakukan didapatkan beberapa jenis batuan yaitu berupa batu pasir dan batuan alluvium.

3. Hasil penelitian kombinasi metode geolis trik dengan metode geomagnet dapat di interpretasikan bahwa batuan penyusun situs purbakala kerajaan Barus yaitu batuan alluvium.

\section{Daftar Pustaka}

Abadiah, N. S., 2014. Pemanfaatan Situs Candi Brahu sebagai Tempat Ritual Agama Budha setelah tahap pemugaran tahun 1995-2011. Jurnal AVATARA. Vol 2. No 1.

[BPS] Badan Pusat Statistik, 2015. Tapanuli Tengah dalam Angka, BPS Pemkab. Tapanuli Tengah, Pandan.

Galili, M.,Weinstein E., A. Ronen Q. R., 1988. Elsevier Holocene sea level changes based on submerged archaeo logical sites off the northern Carmel coast in Argentina, Volume 29, Issue 1. 
Guillot, C., 2002. Lobu Tua Sejarah Awal Barus, Yayasan Pustaka Obor.

Guillot, C., 2008. Histoire de Barus: Le Sitede Lobu Tua II, Etudearcheologiqueet Documents, terj. Daniel Perret \& Atika Suri Fanani, Barus Seribu Tahun Yang Lalu. Kepustakaan Populer Gramedia, Jakarta Selatan.

Himpunan Mahasiswa Geofisika Indonesia, 2012. Geophysical Field Camp 2012, Universitas Gadjah Mada, Yogyakarta.

Jayanti, D. S., Darsono., Budi L., 2012, Identifikasi Situs Candi Bukit Carang Karanganyar Menggunakan Metode Geolistrik Tahanan Jenis Konfigurasi Dipol- Dipol. Indonesian Jurnal of Applied Physics, Vol.2 No.1.

Kanata, B., Teti, Z., 2008. Aplikasi Metode Geolistrik Tahanan Jenis Konfigurasi
Wenner-Schlumberger untuk Survey Pipa Bawah Permukaan, Jurnal Tekno logi ElektroVol. 7 No.2.

Moussavi, A.S.Y., Rosli S.M., Mokhtar S., dan Asadpour R., 2011. Non-invasive Geophysical Techniques for Prospecting the Sungai Batu Archaeological Site, Kedah, Malaysia, IPCBEE Vol.17.

Sharma, P.V., 1997. Environmental and Engineering Geophysics, University Press, Cambridge.

Tamtama, D. R., 2013. Analisis Sebaran Candi Purbakala di Situs Kadisoka dengan Metode Geolistrik Resistivitas Konfigu rasi Winner, Universitas Islam Negeri Sunan Kalijaga, Yogyakarta.

Telford, W. M., Geldart, L.P., Sheriff, R, E., dan Keys, D.A., 1976. Applied Geo physics. University Press, Cambridge. 